\title{
Experimental Study of Heat Pipe Heat Exchanger in Hospital HVAC System for Energy Conservation
}

\author{
Nandy Putra", Trisno Anggoro ${ }^{* \#}$, Adi Winarta ${ }^{\#}$ \\ ${ }^{\#}$ Department of Mechanical Engineering, University of Indonesia, Kampus Baru UI, Depok, 16424, Indonesia \\ E-mail: nandyputra@eng.ui.ac.id, artawina@gmail.com
}

*Center of Technology for Energy Resources and Chemical Industry, The Agency for The Assessment and Application of Technology, Kawasan PUSPIPTEK Serpong, Tangerang Selatan, 15314, Indonesia

E-mail:trisno.anggoro@gmail.com

\begin{abstract}
The hospitals Heating, Ventilation, and Air Conditioning (HVAC) systems consumed large amounts of energy due to the specific requirements that must be met to ensure that environmental conditions were healthy, convenient, and safe. Therefore, to reduce electricity consumption without sacrificing comfort and improving indoor air quality, the utilizing of heat pipe heat exchanger (HPHE) is necessary and highly recommended. An experimental study was conducted to investigate the thermal performance of heat pipe in recovering the heat of an exhaust air from a room simulator. HPHE consisted of several tubular heat pipes with water as a working fluid and staggered by up to six rows. The outer diameter of each heat pipe was $13 \mathrm{~mm}$ and length of $700 \mathrm{~mm}$ with fins mounted on each heat pipe. A series of experiments was conducted to determine the effect of inlet air temperature. The influence of the number of heat pipe rows and air velocity was also investigated. The experiments showed that the higher inlet air temperature, the more effective the HPHE performance became. The cooling capacity of the system had increased. It was indicated by the decrease of air temperature entering the evaporator by $2.4{ }^{\circ} \mathrm{C}$ with the effectiveness of 0.15 . This result was achieved when using six rows HPHE, air velocity $1 \mathrm{~m} / \mathrm{s}$, and evaporator inlet air temperature $45^{\circ} \mathrm{C}$. When air velocity was doubled to $2 \mathrm{~m} / \mathrm{s}$, the system reached the largest amount of heat recovered of $1404.29 \mathrm{~kJ} / \mathrm{hour}$. The overall use of energy in HVAC system from the annual prediction of heat recovery for 8 h/day and 365 days/year would decrease significantly 0.6-4.1 GJ/yr.
\end{abstract}

Keywords - heat pipe; heat recovery; HVAC; effectiveness

\section{INTRODUCTION}

Energy consumption in Indonesia is reported to increase by $3.1 \%$ in 2014 [1]. It has doubled over the last 16 years [2, 3]. Meanwhile, production of oil is slowing down. One of the major energy users in Indonesia is the commercial sector. The hospital is the commercial buildings with a high level of energy demand. The high consumption is due to the need for heating, cooling, ventilation, and high load that must be operated during 24 hours for most facilities, coupled with many medical equipment [4].

Energy Consumption Index for hospitals according to SNI (Indonesian National Standard) 05-3052-1992 is 380 $\mathrm{kWh} / \mathrm{m}^{2}$ year. Based on the results of the survey and energy audit conducted by BPPT and JICA with a sample of buildings in Jakarta show that the energy intensity of buildings hospitals reaches $239 \mathrm{kWh} / \mathrm{m}^{2}$ per year [5].

The Heating, Ventilation and Air Conditioning (HVAC) system is the largest energy consumer in the hospital, which contributed for nearly $60 \%$ of total energy costs that must be paid. The HVAC system (mainly cooling and ventilation) has a significant role in the electric power consumption [6]. $\mathrm{Hu}$ et al. [7] state that if the absorption chiller is not used, then the air conditioning system will consume about $70 \%$ of the total electricity used. It can be shown that the greatest potential of energy saving in the hospital buildings is on the cooling system or the air system.

The hospital HVAC systems, particularly the operating room, consume large amounts of energy due to the requirements regarding accuracy control of the aseptic environment. Improper control of hospital indoor air quality can cause infection and disease [8]. Hospital operating rooms require an installation of air conditioning to ensure healthy indoor environmental conditions so that the patient and medical personnel are more comfortable and safe. It can be done by keeping the environmental parameters (air temperature, humidity ratio, average radiant temperature, and air velocity) within decided ranges and also to ensure acceptable indoor air quality with control, filter, or reduce air contaminants [9], [10]. 
The indoor air quality in the operating room must be sterile. Temperature and humidity are relatively constant and have a relatively low speed to avoid airflow and rotation that can cause recirculation microbes and can interrupt the procedure during surgery. Indoor air that flows out of the operating room should not be mixed up with the supply of fresh air from the outside (without recirculation) [4], [11]. The critical room, such as surgical operating room, usually requires air supply about $15-25 \mathrm{ACH}$, temperature $20^{\circ} \mathrm{C}$ to $24^{\circ} \mathrm{C}$, relative humidity between $20 \%-60 \%$ and a positive air pressure must be maintained [12], [13].

Therefore, it requires a method and equipment that support energy conservation efforts to reduce energy consumption without sacrificing comfort and, at the same time, improving the quality of the air that is clean and sterile. Using heat pipe heat exchanger (HPHE) as a sensible heat recovery is a right solution.

HPHE is the most effective tools for heat recovery [14]. Evaporator section of HPHE is used as the precooling the air before passing through the coil [15]. In conditions where the building needs more fresh air to generate positive pressure in the room, such as the operating room, the use of a heat recovery system is the best option. There is no mixing of the two airflows and thus no transfer of any pollutants that might be carried in the exhaust air of indoor environments [4].

The thermal energy flow from exhausted air can be used to recover sensible heat from the outside air resulting in reduced load on the cooling coil. This application is highly recommended for a system where the indoor and outdoor air is not mixed as in a hospital operating room, as well as biological and chemical laboratories [16], [17].

Several studies have been done on the effectiveness of HPHE especially their application to the HVAC system and can be found in many references [18], [19]. Another researcher such as [15] conducts research to determine the effectiveness of HPHE and the potential energy saving with the use of methanol-nanofluid as working fluid. The use of nanofluid as working fluid HPHE provides total effectiveness coefficient of 1.6 to 3.5 times higher than using pure methanol. Moreover, the use of methanol-silver nanofluid causes the energy savings of around 8.8 to $31.5 \%$ in the evaporator (cooling) and $18-100 \%$ in the condenser (reheating the supply air stream in an air conditioning system).

Thermal performance investigation of HPHE is studied experimentally and theoretically by M. Hassan [20] who uses working fluid R410A, R134a, R22, and R407C. The result shows that the effectiveness of HPHE is more than $25 \%$ to $72 \%$ by increasing evaporator inlet air temperature up to $55{ }^{\circ} \mathrm{C}$ with the air velocity of $1.5 \mathrm{~m} / \mathrm{s}$. The use of $\mathrm{R} 410 \mathrm{~A}$ as a working fluid is recommended because it gives a good result on the performance of HPHE and their effect on the environment is better than the R22 and R134a.

Firouzfar et al. have conducted an experiment on the effectiveness of HPHE in the waste heat recovery process to reduce the cooling load [17]. The result shows that the heat transfer effectiveness is increased by $48 \%$ when the inlet air temperature is $40{ }^{\circ} \mathrm{C}$. The increase in inlet air temperature causes an increase in heat recovery up to $85 \%$.

American Society of Heating, Refrigerating and AirConditioning Engineers (ASHRAE) have examined the use HPHE for heat recovery in hospital operating rooms and laboratories at a low temperature operating conditions $\left(15-55^{\circ} \mathrm{C}\right)$ and using methanol as the working fluid [14]. The result shows that the obtained minimum value of heat transfer rate is still far above the rate of the needed heat transfer. Furthermore, to improve the effectiveness HPHE, the area should have been coupled with fins installed on the heat pipes or by increasing the number of heat pipes.

Ping et al. designs, constructs, and tests three types of thermosyphon HPHE (plate finned copper, spirally-finned steel, and unfinned copper) for medium temperature (lower than $300^{\circ} \mathrm{C}$ ) heat recovery in bakeries using water as working fluid [21]. The best effectiveness of HPHE around $65 \%$ is obtained by finned copper thermosyphon heat exchanger, but the overpressure operating condition may damage the tube of HPHE.

M. Hassan has used computer simulations to predict the performance of 6 rows HPHE without a wick on a tropical building HVAC system with a variety of operating conditions [22]. The obtained results show that the heat transfer increases with the addition of HPHE inclination angle, and by raising the air velocity in the evaporator with the effectiveness value ranges between 0.2-0.6.

Heat pipe heat exchangers have the potential to be applied to hospitals HVAC system, particularly operating room as heat recovery equipment. Therefore, the objective of this study is to examine the thermal performance of HPHE for hospital HVAC systems applications and the amount of heat recovery experimentally.

\section{MATERIAL AND MeTHOD}

\section{A. Design and Specifications}

The detail specifications of HPHE used in this study are shown in Table 1.

TABLE I

HPHE SPECIFICATION

\begin{tabular}{|l|l|}
\hline OD tube & $13 \mathrm{~mm}$ \\
\hline Length of tube & $700 \mathrm{~mm}$ \\
\hline Tube spacing & $\begin{array}{l}\text { transverse: } 50 \mathrm{~mm} \\
\text { longitudinal: } 58 \mathrm{~mm}\end{array}$ \\
\hline Fin & $\begin{array}{l}\text { Copper plate, } 30 \text { fins of each heat } \\
\text { pipe, thickness: } 0.1 \mathrm{~mm}\end{array}$ \\
\hline Number of tube & $\begin{array}{l}2 \text { row }=13 \text { tubes } \\
4 \text { rows }=26 \text { tubes } \\
6 \text { rows }=39 \text { tubes }\end{array}$ \\
\hline Tubes arrangement & staggered \\
\hline
\end{tabular}




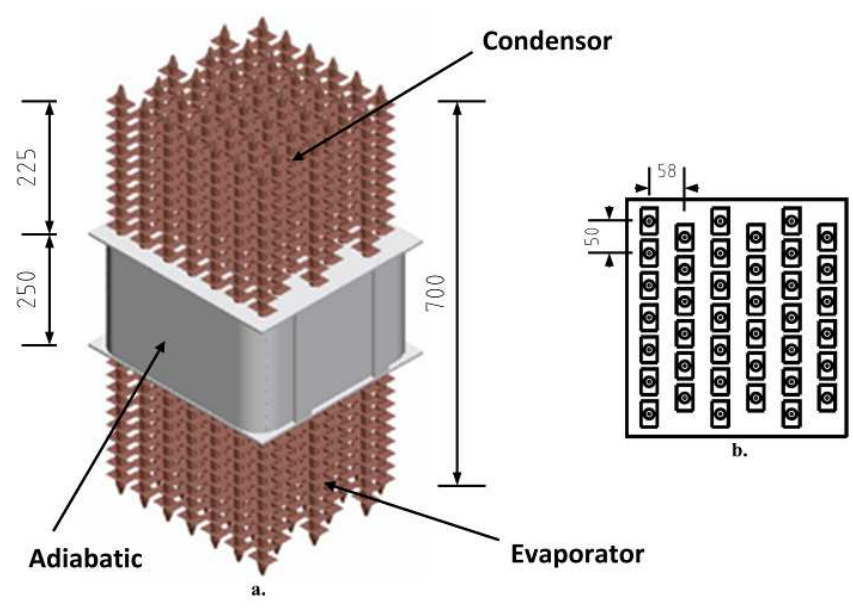

Fig. 1 (a) Dimensions of HPHE with fins are arranged staggered; (b) The distance between the HPHE tubes

In this study, the tubular heat pipe with a length of 700 $\mathrm{mm}$ will be arranged staggered with vertical position. It is placed in the ducting before the cooling coil or evaporator of the air conditioning system. Evaporator section of HPHE installed on the bottom of the duct, condenser section of HPHE located on the top of the duct, and the adiabatic section inserted in the space between ducting. The rows number of HPHE will be varied and cause change-over the amount of a heat pipe that was used

Heat pipes are made of copper material, which uses water as working fluid with a ratio of $50 \%$ and adds 30 sheets fins in each heat pipe to increase the heat transfer area. Each heat pipe is $22.5 \mathrm{~cm}$ of length on each part of the evaporator and condenser, whereas the adiabatic section has a length of 25 $\mathrm{cm}$ as shown in Fig. 1 (a). Fig. 1 (b) illustrates the distance between the pipes in HPHE, transversal direction by $50 \mathrm{~mm}$ by $58 \mathrm{~mm}$ in the longitudinal direction.

\section{B. Experimental Setup}

Fig. 2 shows the test rig. It consists of some equipment such as fan on the inlet and outlet side, HPHE, cooling coil (evaporator of the air conditioner), condensers, the room
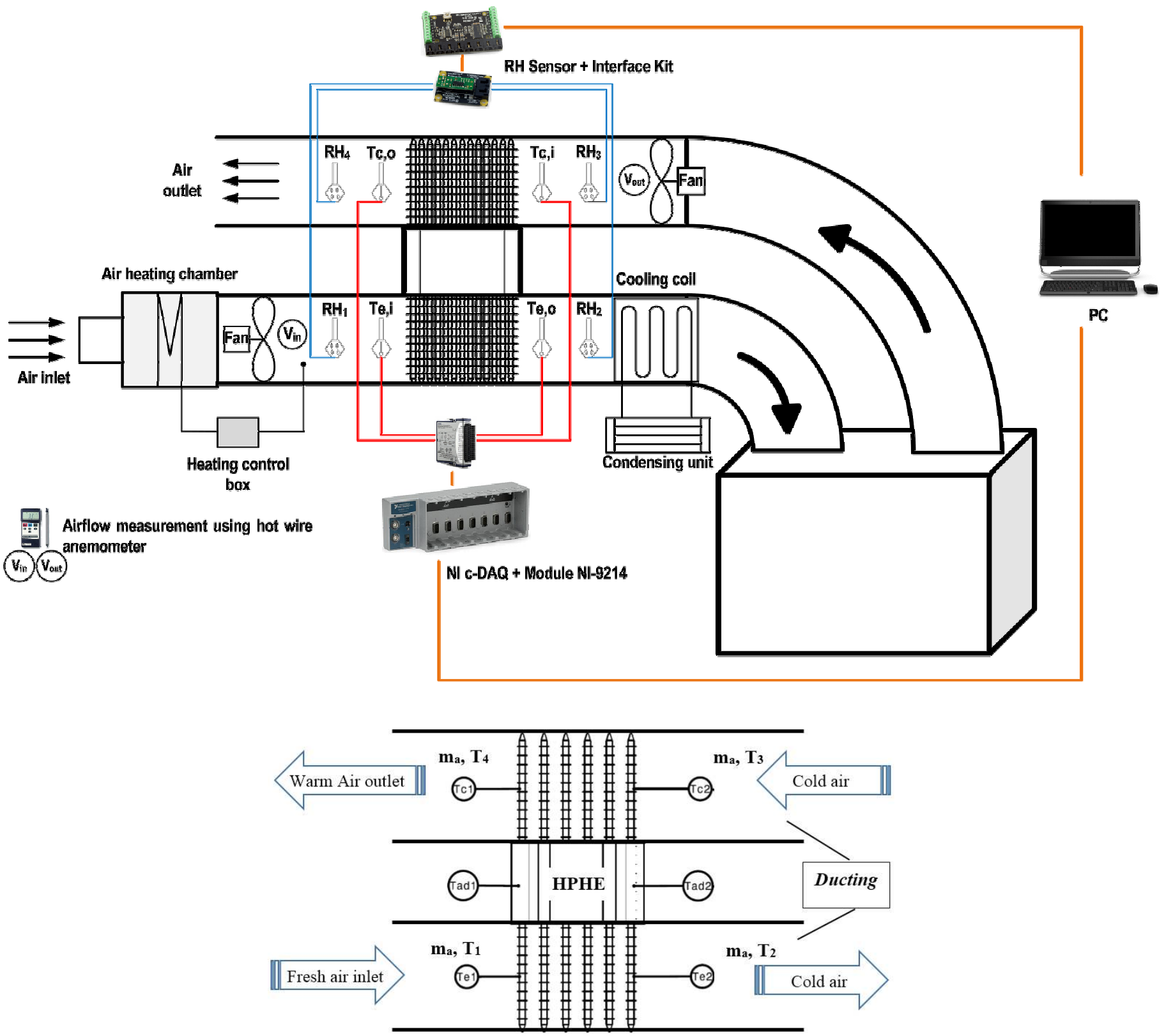

Fig. 2 Test rig 
simulator, and several measuring devices that are connected to ducting with dimensions of $300 \mathrm{~mm} \mathrm{x} 470 \mathrm{~mm}$. The placement of heat pipes in the ducting and direction of airflow in and out also shown in Fig. 2.

HPHE evaporator was installed inside the ducting before the cooling coil of commercial air conditioning with a capacity of 9000 BTU. Commercial air conditioning was expected to be able to condition the room with length 310 $\mathrm{cm}$, width $150 \mathrm{~cm}$, and height $150 \mathrm{~cm}$. The setting of evaporator inlet air temperature was done in the air heating chamber using the temperature controller.

A temperature controller (ON/OFF switch) on the $6 \mathrm{~kW}$ heating element using PID control (Proportional Integral Derivative) with a temperature tolerance $\pm 0.3^{\circ} \mathrm{C}$ of the setting value was used in this experiment. Inlet air temperature range was set from 30 to $45^{\circ} \mathrm{C}$.

Inlet fan blows fresh air into the ducting where the mass flow rate can be set between 1 to $2 \mathrm{~m} / \mathrm{s}$, and an airflow rate is measured using a hot wire anemometer. Inlet air is to be cooled (pre-cooled) when it comes in contact with the evaporator section of HPHE. Furthermore, the cooling process is conducted by cooling the coil to decrease the temperature of room simulator. Exhaust air from the room simulator flows into the upper side of ducting with a lower temperature than the temperature of the inlet air as it will be used to cool the condenser section of HPHE.

Temperatures were measured using the K-type thermocouple with a total of five thermocouples which are mounted on ducting and for ambient. Four thermocouples are installed inside the ducting (before and after HPHE) to measure the air temperature and one thermocouple to measure ambient temperature. The measurement system was equipped with NI DAQ modules 9213 and 9211 are attached to the chassis NI cDAQ 9172 to measure the temperature. It was connected to a personal computer using USB port. The measurement of relative humidity using four RH sensors, from Phidget Inc. was linked to the interface kit and installed in the ducting (before and after HPHE) and one sensor to measure ambient conditions. All of the measurement processes was done at steady state condition.

Fig. 3 presents the test rig simulator of HVAC system in the Heat Transfer Laboratory UI. There are air heating chamber, ducting, fans, cooling system, room simulator, and control panel box.

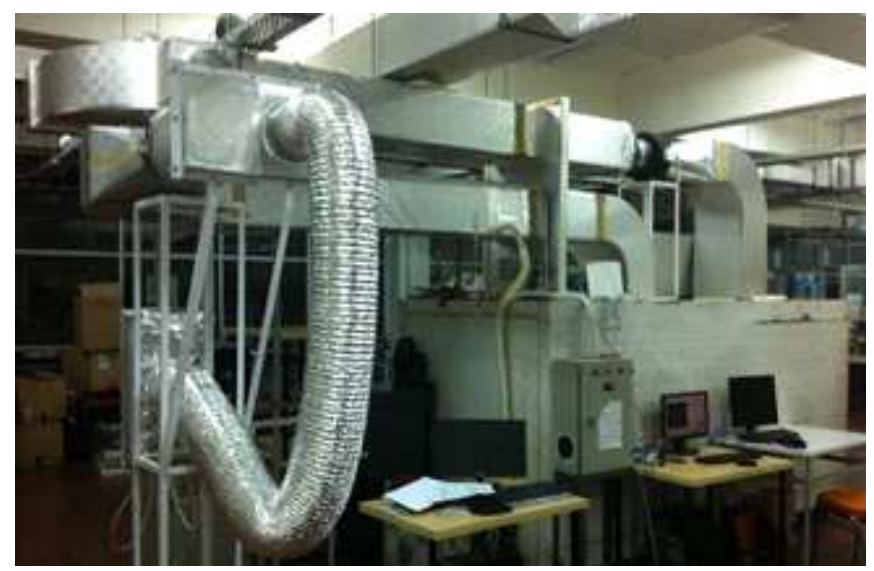

Fig. 3 Equipment Test Simulator
Fig. 4 shows air heating chamber to control air inlet temperature before entering ducting. Outlet air from heating chamber is connected to main ducting using flexible ducting.

Fig. 5 illustrates the placement of the heat pipe in the

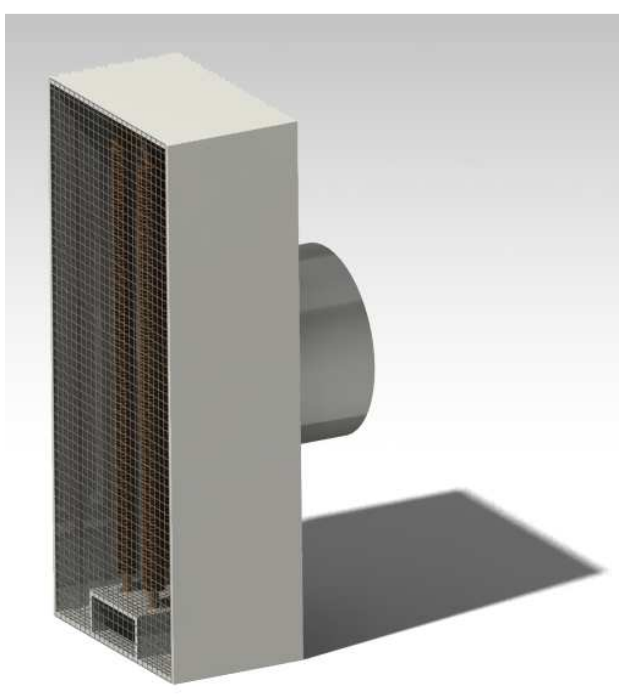

Fig. 4 Air heating chamber

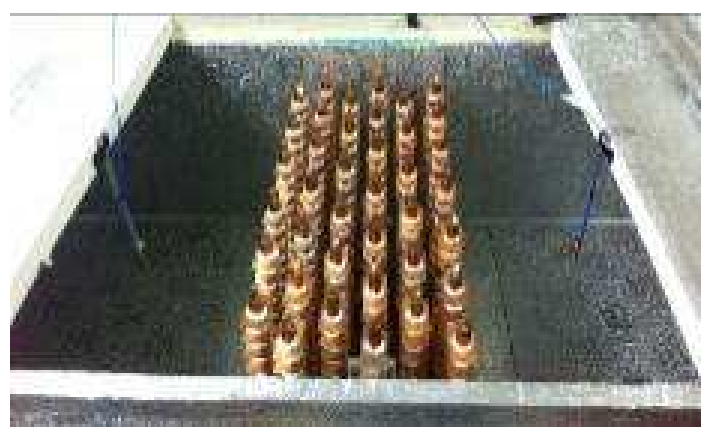

Fig. 5 HPHE placement in the ducting

ducting. The number of rows can be changed by disassembling HPHE at the top of ducting.

\section{Effectiveness Calculation Procedure}

The sensible effectiveness could be used to determine the thermal performance of HPHE from the air side. Effectiveness is the most relevant parameter to describe the performance HPHE. Effectiveness in Equation (1) is defined as the ratio of the actual heat transfer to the maximum heat transfer in a heat exchanger.

$$
\begin{gathered}
\mathcal{E}=\frac{Q_{a c t}}{Q_{\max }} \\
\mathcal{E}=\left(\frac{T_{e, i}-T_{e, o}}{T_{e, i}-T_{c, i}}\right)
\end{gathered}
$$

Dry bulb temperature can be used to calculate the effectiveness of the sensible as given in Equation (2). In 
HPHE being studied, sensible and total effectiveness can be considered about the same $\left(\varepsilon_{\text {sen }}=\varepsilon_{\text {tot }}\right)$.

Therefore, in this study, the sensible effectiveness was used to determine the performance HPHE on the air side and was obtained by measuring the air temperature.

The determination of the sensible effectiveness applies some following assumptions [18], [23]:

- HPHE operates as sensible heat exchanger equipment.

- HPHE operates at steady-state conditions during the experiments (the mass flow rate for both section and the temperature at all measurement points were steady).

- HPHE was fully insulated and no incoming energy from outside or loss from HPHE.

- Energy transfer between the evaporator and condenser section of HPHE are equal and opposite. Due to the equal mass flow rate in both section, so it can be assumed that $c_{p}$ is constant, so that $\left(T_{e, i}-T_{e, o}\right)=$ $\left(T_{c, o}-T_{c, i}\right)$

- The air flow has been in steady state at the measurement point.

\section{RESULTS AND DISCUSSION}

From the experimental data by placing a thermocouple at some point inside the ducting with different HPHE rows number, air velocity, and inlet air temperature, can be obtained the performance of heat pipe heat exchanger and the amount of heat recovery.

\section{A. Heat Pipe Heat Exchanger Performance}

The thermal performance of HPHE can be determined from the value of its effectiveness.

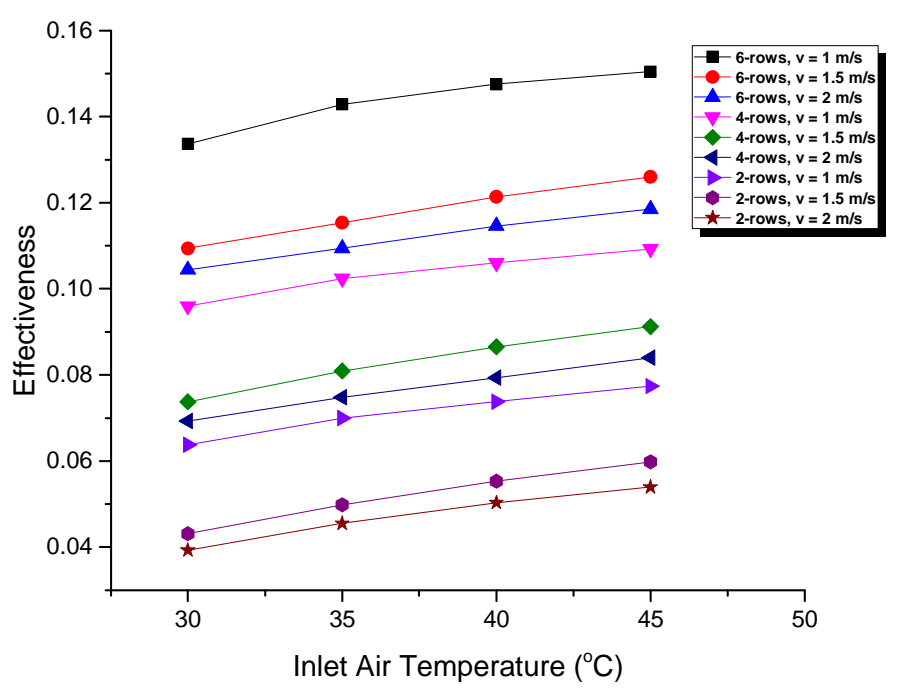

Fig. 6 The effectiveness of heat pipe heat exchanger

Results of the experiment are to determine the effectiveness HPHE with variations or operating parameters as shown in Fig. 6. It illustrates that the greatest effectiveness 0.15 was obtained when using six rows HPHE with the air velocity $1 \mathrm{~m} / \mathrm{s}$ at a temperature of $45^{\circ} \mathrm{C}$. At the same condition showed that the evaporator inlet air temperature has decreased to $2.4^{\circ} \mathrm{C}$. Moreover, the effectiveness of HPHE increased by raising the evaporator air inlet temperature.

These results indicated that HPHE was already working, where the evaporator of HPHE absorbed heat in the air inlet. In that section, a precooling process occurred, characterized by a decrease in air temperature after evaporator of HPHE, thus reducing the initial sensible cooling load at cooling coil. It allows the air reach the dew point more quickly. The condenser of HPHE functioned to reheat the cold air that was absorbed by HPHE to cool the condenser section. It caused an increase in outlet air temperature.

Other parameters such as air flow rate also affect the value of effectiveness. The results showed that the effectiveness of HPHE increased systematically in line with the decrease in air flow velocity. During the air velocity 1 $\mathrm{m} / \mathrm{s}$, the value of effectiveness was better than the airflow velocity of $1.5 \mathrm{~m} / \mathrm{s}$ and $2 \mathrm{~m} / \mathrm{s}$. It occurs because decrease airflow causes the absorption of heat by HPHE become maximal. Thus, the process of heat transfer between air and heat pipe occurs well.

Furthermore, the row number of HPHE also affects thermal performance. Increasing the row number of heat pipes causes the effectiveness of HPHE increases systematically. More heat pipes result in the significant amount of heat can be absorbed. The test results with several parameters have a consistent trend with some research results [20], [21], [24].

The experimental result shows that the effectiveness of HPHE has increased systematically by increasing the evaporator inlet air temperature and the number of rows HPHE as well as a decrease in airflow velocity.

\section{B. Heat Recovery}

Heat recovery process in HPHE application can occur in the evaporator and condenser. In this experiment, heat recovery was only observed in the precooling (evaporator HPHE) because it provides a direct impact on the reduction in the energy consumption of the system.

The amount of heat recovery can be achieved in the use of HPHE in the HVAC system with several parameters of the experiment was shown in Table 2 and Fig. 7.

This result presents that the greatest value of heat recovery was obtained equal to $1404.29 \mathrm{~kJ} /$ hour when using six rows HPHE at the evaporator inlet air temperature $45^{\circ} \mathrm{C}$ and the air velocity $2 \mathrm{~m} / \mathrm{s}$. Whereas for the smallest value of the heat recovery was obtained when using two rows HPHE at the evaporator inlet air temperature of $30^{\circ} \mathrm{C}$ and the air velocity of $1.5 \mathrm{~m} / \mathrm{s}$ was equal to $204.72 \mathrm{~kJ} /$ hour.

Increasing the number of rows and evaporator inlet air temperature significantly influences the increase in heat recovery from HPHE. However, the magnitude of the maximum and minimum heat recovery did not change significantly when the evaporator inlet air velocity was increased at the condition two or four rows HPHE.

Increasing air flow velocity will increase the mass flow rate of air, thus increasing the rate of heat transfer between the air and HPHE. Therefore, heat recovery will be increased. 


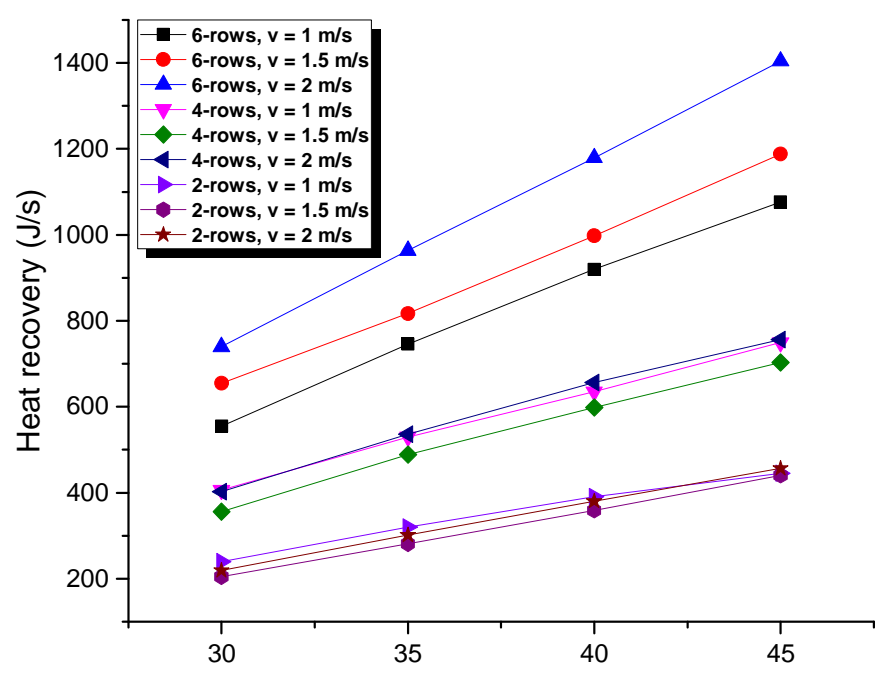

Inlet Air Temperature $\left({ }^{\circ} \mathrm{C}\right)$

Fig. 7 Heat recovery on evaporator HPHE

TABLE III

AMOUNT OF HEAT RECOVERY ON EVAPORATOR HPHE

\begin{tabular}{|c|c|c|c|c|}
\hline \multirow{7}{*}{$\begin{array}{c}6 \\
\text { row }\end{array}$} & \multirow{3}{*}{$\begin{array}{c}\text { Temperature } \\
\left({ }^{\circ} \mathrm{C}\right)\end{array}$} & \multicolumn{3}{|c|}{ Heat Recovery $(\mathrm{kJ} / \mathrm{h})$} \\
\hline & & \multicolumn{3}{|c|}{ Air Velocity $(\mathrm{m} / \mathrm{s})$} \\
\hline & & 1 & 1.5 & 2 \\
\hline & 30 & 554,77 & 654,92 & 739,73 \\
\hline & 35 & 745,64 & 816,86 & 963,64 \\
\hline & 40 & 920,18 & 997,91 & 1179,16 \\
\hline & 45 & 1076,23 & 1188,20 & 1404,29 \\
\hline \multirow{7}{*}{$\begin{array}{c}4 \\
\text { row }\end{array}$} & \multirow{3}{*}{$\begin{array}{c}\text { Temperature } \\
\left({ }^{\circ} \mathrm{C}\right)\end{array}$} & \multicolumn{3}{|c|}{ Heat Recovery $(\mathrm{kJ} / \mathrm{h})$} \\
\hline & & \multicolumn{3}{|c|}{ Air Velocity (m/s) } \\
\hline & & 1 & 1.5 & 2 \\
\hline & 30 & 406,36 & 356,21 & 402,34 \\
\hline & 35 & 529,87 & 489,19 & 536,09 \\
\hline & 40 & 634,87 & 598,25 & 656,35 \\
\hline & 45 & 749,83 & 702,96 & 756,49 \\
\hline \multirow{7}{*}{$\begin{array}{c}2 \\
\text { row }\end{array}$} & \multirow{3}{*}{$\begin{array}{c}\text { Temperature } \\
\left({ }^{\circ} \mathrm{C}\right)\end{array}$} & \multicolumn{3}{|c|}{ Heat Recovery (kJ/h) } \\
\hline & & \multicolumn{3}{|c|}{ Air Velocity (m/s) } \\
\hline & & 1 & 1.5 & 2 \\
\hline & 30 & 239,53 & 204,72 & 219,09 \\
\hline & 35 & 320,76 & 280,97 & 301,74 \\
\hline & 40 & 391,10 & 359,16 & 380,51 \\
\hline & 45 & 445,34 & 440,60 & 456,59 \\
\hline
\end{tabular}

From these results, it can be concluded that the use of six rows HPHE was an optimum design compared to the use of two or four rows. The addition of air velocity will increase the mass flow rate of air that can increase the heat transfer rate between the air and HPHE thus increasing the value of heat recovery.

\section{CONCLUSIONS}

Heat pipes can be used as a heat exchanger (heat pipe heat exchanger). In the present study, heat pipe heat exchanger was already working. HPHE can be applied to hospitals HVAC system, particularly operating room as heat recovery equipment. The influence of the rows number of the heat pipe, evaporator air inlet temperature, and air velocity on the thermal performance of HPHE and the amount of heat recovery was investigated experimentally. The cooling capacity of the system increased as a result of the precooling process. It was indicated by a decrease in the temperature of air entering the evaporator up to $2.4^{\circ} \mathrm{C}$ with the effectiveness 0.15 when using six rows HPHE, air velocity of $1 \mathrm{~m} / \mathrm{s}$, and the evaporator inlet air temperature of $45^{\circ} \mathrm{C}$. HPHE thermal performance increase in line with the rise in the HPHE rows number and evaporator inlet air temperature and a decrease in airflow velocity. The largest amount of heat recovery achieved $1404.29 \mathrm{~kJ} /$ hour when using six rows HPHE, the evaporator inlet air temperature of $45^{\circ} \mathrm{C}$, and an air velocity of $2 \mathrm{~m} / \mathrm{s}$. Whereas for the smallest value of heat recovery was obtained equal to $204.72 \mathrm{~kJ} /$ hour when using two rows $\mathrm{HPHE}$, the evaporator inlet air temperature of $30^{\circ} \mathrm{C}$, and an air velocity of $1.5 \mathrm{~m} / \mathrm{s}$. If the operating room to operating for 8 hours/day and 365 days/year, the reduction in energy consumption at the hospital HVAC system can be seen from the predicted amount of heat recovery which reached 4.1 $\mathrm{GJ} /$ year.

\section{NOMENCLATURE}

$c_{p} \quad$ specific heat of the ambient air

HPHE heat pipe heat exchanger

$Q$ heat transfer rate W

$T$ temperature ${ }^{\circ} \mathrm{C}$

Greek letters

$\varepsilon \quad$ effectiveness

Subscripts

act actual

sen sensible

max maximum

tot total

$c \quad$ condenser

e evaporator

$i \quad$ inlet

$o \quad$ outlet

\section{ACKNOWLEDGMENT}

The author would like to thank the PUPT - Ministry of Research, Technology, and Higher Education for funding this research.

\section{REFERENCES}

[1] H. Setiawan, "Geothermal Energy Development in Indonesia: Progress, Challenges and Prospect," International Journal on Advanced Science, Engineering and Information Technology, vol. 4, pp. 224-229, 2014.

[2] BP. (2015, BP Statistical Review 2015. Pasar Energi Indonesia di 2014.

[3] T. K. Hariadi, P. J. Prahara, S. B. Lesmana, and R. Saidi, "Energy Efficiency and Policy Analysis for Household in DI Yogyakarta (Yogyakarta special Region) Indonesia," International Journal on Advanced Science, Engineering and Information Technology, vol. 6, pp. 329-333, 2016.

[4] C. A. Balaras, E. Dascalaki, and A. Gaglia, "HVAC and indoor thermal conditions in hospital operating rooms," Energy and Buildings, vol. 39, pp. 454-470, 4// 2007. 
[5] B2TE-BPPT, Perencanaan Efisiensi Dan Elastisitas Energi 2012. Jakarta: BPPT Press, 2012.

[6] A. Teke and O. Timur, "Assessing the energy efficiency improvement potentials of HVAC systems considering economic and environmental aspects at the hospitals," Renewable and Sustainable Energy Reviews, vol. 33, pp. 224-235, 5// 2014.

[7] S. C. Hu, J. D. Chen, and Y. K. Chuah, "energy cost and consumption in a large acute hospital," International Journal on Architectural Science, vol. 5, 2003.

[8] M. Leung and A. H. S. Chan, "Control and management of hospital indoor air quality," Med Sci Monit, vol. 12, 2006.

[9] L. Perez-Lombard, J. Ortiz, and I. R. Maestre, "The map of energy flow in HVAC systems," Applied Energy, vol. 88, pp. 5020-5031, $12 / / 2011$.

[10] S. K. M. Rao, "HVAC in hospitals," Journal of Patient Safety \& Infection Control, vol. 3, p. 35, 5// 2015.

[11] ASHRAE and ANSI/ASHRAE, "Standard 62-2001 Ventilation for acceptable indoor air quality," ed. Atlanta: American Society of Heating, Refrigerating and Air-Conditioning Engineers, Inc., 2001.

[12] ANSI/ASHRAE/ASHE, "Standard 170-2013," in Ventilation of Health Care Facilities, ed. Atlanta: American Society of Heating, Refrigerating and Air-Conditioning Engineers, Inc., 2013.

[13] E. E. Khalil and R. Kameel, "Requirements of Air-Conditioning Systems Developments in Hospitals and Critical Healthcare Facilities," in 7th Biennial Conference on Engineering Systems Design and Analysis, Manchester, United Kingdom, 2004.

[14] S. H. Noie-Baghban and G. R. Majideian, "Waste heat recovery using heat pipe heat exchanger (HPHE) for surgery rooms in hospitals," Applied Thermal Engineering, vol. 20, pp. 1271-1282, $10 / 1 / 2000$.

[15] E. Firouzfar, M. Soltanieh, S. H. Noie, and M. H. Saidi, "Investigation of heat pipe heat exchanger effectiveness and energy saving in air conditioning systems using silver nanofluid," International Journal of Environmental Science and Technology, vol. 9, pp. 587-594, 2012.
[16] L. Pérez-Lombard, J. Ortiz, J. F. Coronel, and I. R. Maestre, "A review of HVAC systems requirements in building energy regulations," Energy and Buildings, vol. 43, pp. 255-268, 2// 2011.

[17] M. A. Abd El-Baky and M. M. Mohamed, "Heat pipe heat exchanger for heat recovery in air conditioning," Applied Thermal Engineering, vol. 27, pp. 795-801, 3// 2007.

[18] Y. H. Yau and M. Ahmadzadehtalatapeh, "Performance Analysis of a Heat Pipe Heat Exchanger Under Different Fluid Charges," Heat Transfer Engineering, vol. 35, pp. 1539-1548, 2014/12/12 2014.

[19] W. Xiao Ping, P. Johnson, and A. Akbarzadeh, "Application of heat pipe heat exchangers to humidity control in air-conditioning systems," Applied Thermal Engineering, vol. 17, pp. 561-568, 6// 1997.

[20] M. Hassan, "Investigation of Performance of Heat Pipe as Heat Exchanger Using Alternative Refrigerants," Journal of Energy Engineering, vol. 139, pp. 18-24, 2013.

[21] A. R. Lukitobudi, A. Akbarzadeh, P. W. Johnson, and P. Hendy, "Design, construction and testing of a thermosyphon heat exchanger for medium temperature heat recovery in bakeries," Heat Recovery Systems and CHP, vol. 15, pp. 481-491, 1995/07/01 1995.

[22] Y. H. Yau and A. S. Tucker, "The performance study of a wet sixrow heat-pipe heat exchanger operating in tropical buildings," International Journal of Energy Research, vol. 27, pp. 187-202, 2003.

[23] Y. H. Yau, "Experimental thermal performance study of an inclined heat pipe heat exchanger operating in high humid tropical HVAC systems," International Journal of Refrigeration, vol. 30, pp. 1143$1152,11 / / 2007$.

[24] Y. H. Yau and M. Ahmadzadehtalatapeh, "Heat Pipe Heat Exchanger and Its Potential to Energy Recovery in The Tropics," Thermal Science, vol. 19, pp. 1685-1697, 2015. 